\title{
Reinforced Concrete Corbel's Behavior using Strut and Tie Model
}

\author{
Mutmainnah Rahman Putri \\ Ministry of Public Works and Housing, Jakarta, INDONESIA \\ mutmainnah.rahman.putri@gmail.com
}

\begin{abstract}
Reinforced concrete (RC) corbel is one of a disturbed region of elements of the structure. SNI 2847: 2013 as a guideline from Ministry of Public Works provides the design of RC corbels by the conventional method and with Strut and Tie Model (STM). The aim of this study is to determine and compare the behaviors of corbels experimentally that designed with both methods. The testing was conducted on two series of specimens and each series consisted of two specimens. Group 1 was designed using conventional method while group 2 designed using Strut and Tie Model. The axial column was tested under $50 \mathrm{kN}$ fixed axial loads and corbels was tested under monotonic loads gradually increased up to failure. The results showed that with the provided steel and compressive strength of concrete, the shear capacity using the conventional method by analysis and experimental respectively were $363.164 \mathrm{kN}$ and $345.7 \mathrm{kN}$, while the shear capacity using Strut and Tie Model by analysis and experimental respectively were $306.953 \mathrm{kN}$ and $299.35 \mathrm{kN}$. The shear capacity of specimens using conventional method was $13.40 \%$ greater than by using Strut and Tie Model and the shear capacity for each conventional and STM method were 1.9232 and 1.6653 greater than designated load.
\end{abstract}

Keywords: corbel; reinforced concrete; strut and tie; experiment; shear capacity.

\section{INTRODUCTION}

Reinforced concrete (RC) corbel defined as short cantilevers having a shear-span-to-depth ratio, $a / d$ less than one. RC corbel is one of a disturbed region (Dregion) of elements of the structure. D-region is the region where Bernoulli's hypothesis cannot be applied and the strain distribution is significantly nonlinear as a result of geometric discontinuity (a sudden change of geometry), static discontinuity by concentrated loads (regions near the support or concentrated load), or both geometric and static discontinuity. There are various analytical methods for the D-region, one of the methods that have been used and developed is the Strut and Tie Method (STM).

In Indonesia, Ministry of Public Works issued National Standard of Indonesia (SNI - Standar Nasional Indonesia) on the requirement of the reinforced concrete for building including the Strut and Tie method as a method of calculation in Appendix A (ACI Committee, 2002), which has been recommended as a design procedure for the D-region (ACI Committee, 2005; ACI Committee, 2014). This research is aimed to design the reinforced concrete corbels with Strut and Tie Method and conventional method based on SNI 2847: 2013 (Ministry of Public Works, 2013) using plane section concept. Both methods will obtain a different area and arrangement of reinforcement steel, which is then verified with experimental results and then compared the actual load capacity and the behavior of structures with the results of analysis based on both methods.

\section{LITERATURE REVIEW}

\subsection{Strut and Tie Model}

The structural components are sometimes categorized into Beam regions or Bernoulli regions (B-regions) and Disturbed region (D-regions). In beam regions, it is reasonable to assume that there is a linear variation in strain over the depth of the section following Bernoulli's hypothesis, whereas, in Disturbed regions, there is a complex variation in strain, occurring near abrupt changes in geometry (geometrical discontinuities) or concentrated forces (statical discontinuities) (Attaullah, et al., 2011).

In ACI 318M-11 (ACI Committee, 2011), Strut and Tie Model is defined as a truss model of a structural member, or that of a D-region in such a member, made up of struts and ties connected at nodes, capable of transferring the factored loads to the supports or to adjacent B-regions (see Figure 1).

A truss model of Strut and Tie Model (Fu, et al., 2011) can be selected with this three following ways: Elastic stress trajectories from the linear elastic analysis as shown in Figure 2, load path method and standard model as shown in Figure 3. 


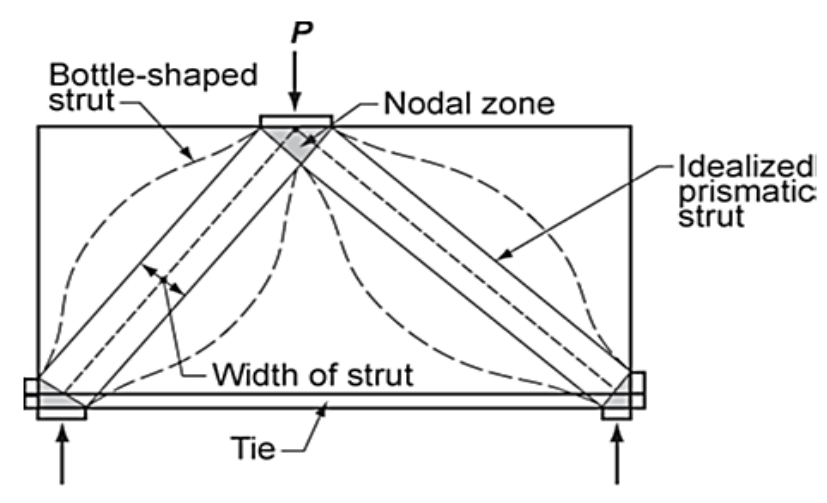

Figure 1. Description of Strut and Tie Model (ACI Committee, 2011)

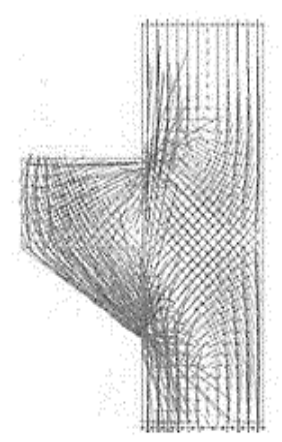

Figure 2. Principal stress trajectories of the corbel.

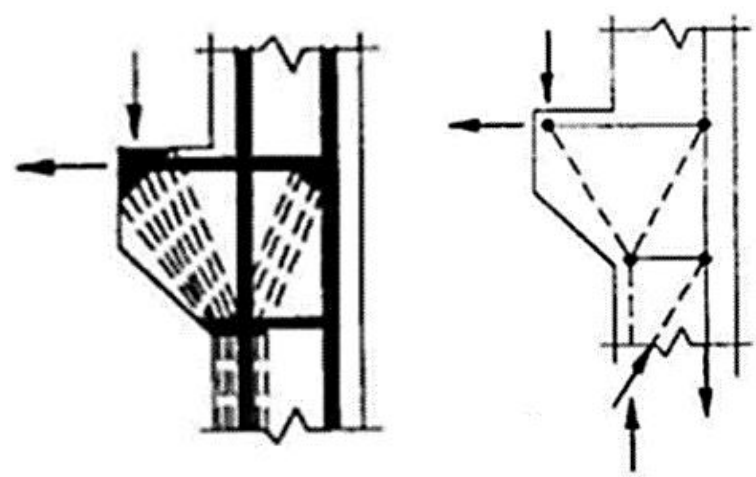

Figure 3. Standard truss model of the corbel.

\subsection{The Design of Corbels}

\subsubsection{Provisions based on SNI 2847:2013 Chapter} 11.8.

The types of reinforcement that should be designed are as follows

a) Shear-friction reinforcement

$$
A_{v f}=\frac{V_{n}}{f_{y} \mu}
$$

where $A_{v f}$ is the area of shear-friction reinforcement, $f_{y}$ is specified yield strength of reinforcement, and $\mu$ is a coefficient of friction (concrete placed monolithically $\mu$ is 1,4 dan concrete placed non-monolithically $\mu$ is 1 ).

b) Flexural reinforcement

$$
A_{f}=\frac{M_{u}}{\phi f_{y} 0.85 d}=\frac{V_{u} a+N_{u c}(h-d)}{\phi f_{y} 0.85 d}
$$

where $A_{f}$ is the area of reinforcement resisting factored moment, $M_{u}$ is factored moment at the section, $N_{u c}$ is factored horizontal tensile force, $a$ is the shear span, and $h$ is the height of member.

c) Tensile reinforcement

$$
A_{n}=\frac{N_{u c}}{\phi f_{y}}
$$

where $A_{n}$ is the area of reinforcement resisting tensile force.

Factored tensile force, $N_{u c}$ shall not be taken less than $0.2 V_{u}$

$$
N_{u c \min }=0.2 V_{u}
$$

d) Primary reinforcement

$$
\begin{aligned}
& A_{s}=\frac{2}{3} A_{v f}+A_{n} \\
& A_{s}=A_{f}+A_{n}
\end{aligned}
$$

where $A_{s}$ is the area of primary reinforcement

e) Minimum primary reinforcement

$$
A_{s \min }=0.04 \frac{f^{\prime}{ }_{c}}{f_{y}} b d
$$

Where $f^{\prime}{ }_{c}$ is the specified compressive strength of concrete, $b$ is the width of the member, and $d$ is the effective depth.

f) Closed stirrups reinforcement

$$
A_{h}=\frac{1}{2}\left(A_{s}-A_{n}\right)
$$

where $A_{h}$ is the area of closed-stirrups reinforcement. 
Geometry parameters of corbel are shown in Figure 4.

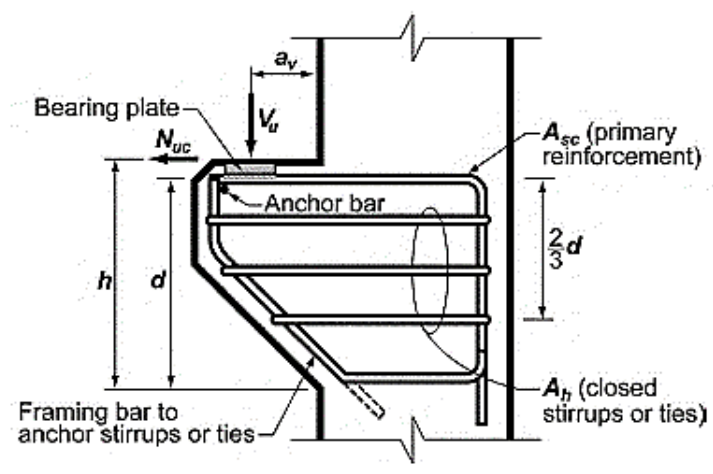

Figure 4. Geometry parameters of corbel (Ministry of Public Works, 2013)

\subsubsection{Provisions of Strut and Tie Model in SNI 2847:2013 Appendix A}

The basic concept for designing structural concrete members using Strut and Tie Model is idealized as a system truss, where the design of strut, tie, and nodal shall be based on principles of limit state design.

$\phi F_{n} \geq F_{u}$

where $F_{u}$ is factored force acting in a strut, tie, bearing area, or nodal zone in a strut-and-tie-model, $F_{n}$ is the nominal strength of a strut, tie, or nodal zone and $\phi$ is strength reduction factor $(\phi=0.75)$.

a) Strength of struts

The nominal compressive strength of a strut without longitudinal reinforcement shall be taken as the smaller value of

$$
F_{n s}=f_{c e} A_{c s}
$$

at the two ends of the strut, where $A_{c s}$ is the crosssectional area at one end of the strut and $f_{c e}$ is the effective compressive strength of the concrete.

The effective compressive strength of the concrete $f_{c e}$ in a strut shall be taken as

$$
f_{c e}=0.85 \beta_{s} f^{\prime}
$$

where the value of $\beta_{s}$ is determined by strut geometry.

b) Strength of ties
The nominal strength of a tie shall be taken as

$$
F_{n t}=A_{t s} f_{y}+A_{t p}\left(f_{s e}+\Delta f_{p}\right)
$$

where $A_{t s}$ is the area of non-prestressed reinforcement in tie and $A_{t p}$ is the area of prestressing steel in tie where $\left(f_{s e}+\Delta f_{p}\right)$ shall not exceed $f_{p y}$ and $A_{t p}$ is zero for nonprestressed members.

c) Strength of nodal zones

The nominal compression strength of a nodal zone is as follows

$$
F_{n n}=f_{c e} A_{n z}
$$

where $f_{c e}$ is the effective compressive strength of the concrete in the nodal zone and $A_{n z}$ is the area of the face of the nodal zone on which $F_{u}$ acts, taken perpendicular to the line of action of $F_{u}$.

The effective compressive strength on a face of a nodal zone due to the strut and tie forces shall not exceed the value given by:

$$
f_{c e}=0.85 \beta_{n} f_{c}^{\prime}
$$

where the value of $\beta_{n}$ is determined by the type of nodal.

\subsubsection{Strut and Tie Model design procedure}

The following steps explain design procedure for Strut and Tie Model:

a) Divide the structure into $B$ and $D$ region

b) Checking bearing capacity at loading and support location

c) Established strut-and-tie model

d) Resolving the assumed truss (strut-and-tie model) to determine member forces

e) Verifying the strut capacities

f) Checking the strength of nodal zones

g) Design of ties

h) Detail of reinforcement

\section{RESEARCH METHODOLOGY}

This research was conducted in Structural Engineering Laboratory, Department of Civil and Environmental Engineering, Faculty of Engineering, Universitas Gadjah Mada. 


\subsection{Specimen details}

Test specimens classified in two series and each series consisted of two columns with one-sided corbel. Series 1 was designed using conventional method and Series 2 was designed using Strut and Tie Model due to a static load. The truss model used for designing is shown in Figure 5 and the detail of steel reinforcement using both methods are shown in Figure 6 and Figure 7. The recapitulation of specimens are given in Table 1 and the differences between $A_{s}$ and $A_{h}$ provided both methods given in Table 2.

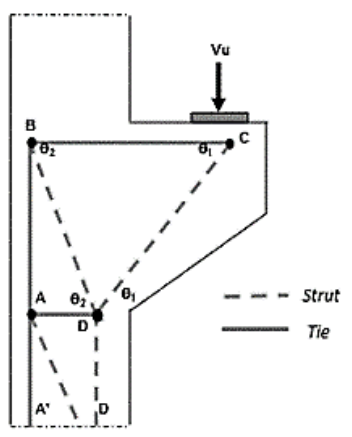

Figure 5. Strut and Tie Model for designing corbels.
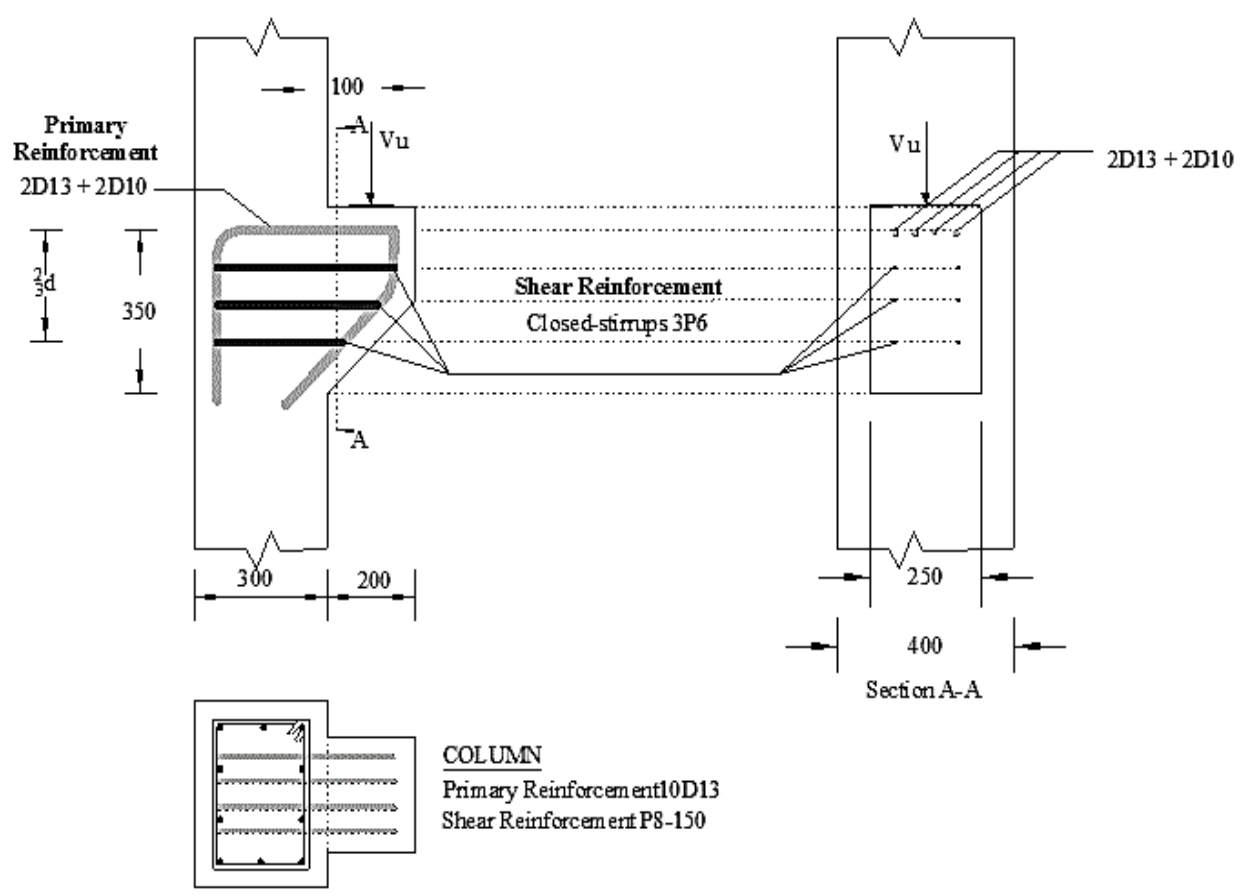

\section{COLUMN}

Primary Reinforcement10D13

Shear Reinforcem ent P8-150

Figure 6. Detail of reinforcement of corbels designed using conventional method

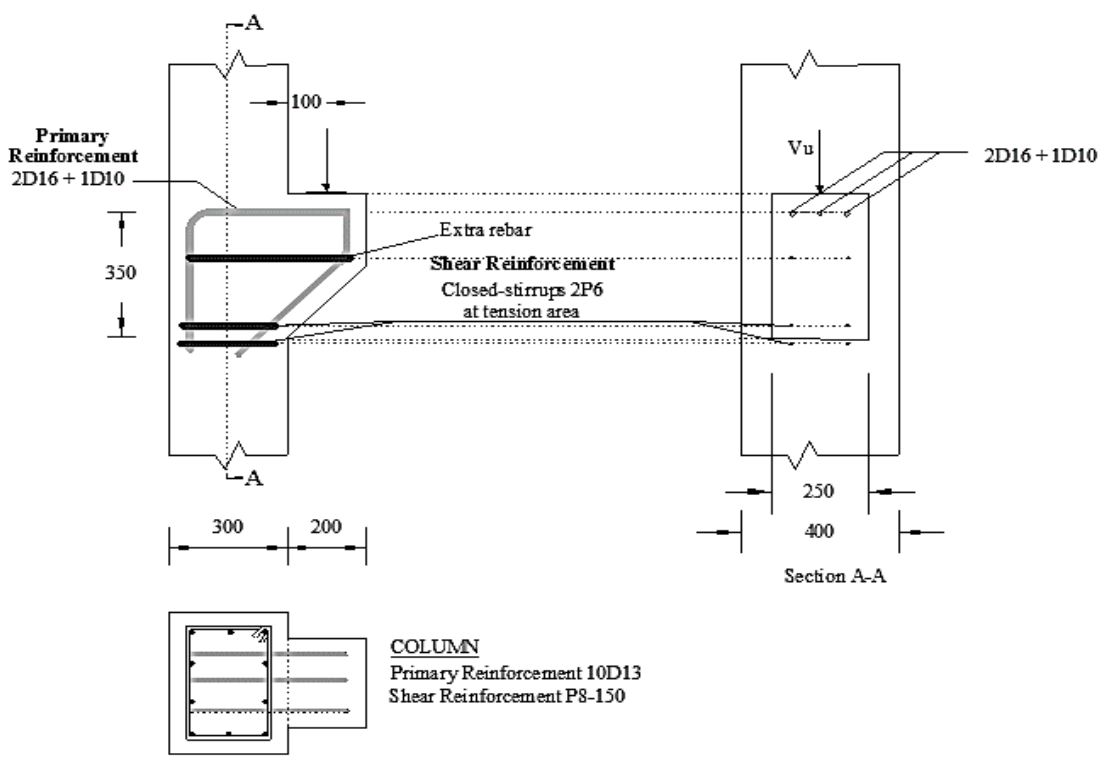

Figure 7. Detail of reinforcement of corbels designed using Strut and Tie Model 
Table 1. Detail of specimens designed using conventional and STM method

\begin{tabular}{|c|c|c|c|c|c|c|c|}
\hline $\begin{array}{l}\text { Design } \\
\text { Method }\end{array}$ & $\begin{array}{l}\text { Number of } \\
\text { specimens }\end{array}$ & $\begin{array}{l}\text { Column } \\
\text { Dimensions } \\
(\mathrm{mm})\end{array}$ & $\begin{array}{l}\text { Corbel } \\
\text { Dimensions } \\
(\mathrm{mm})\end{array}$ & 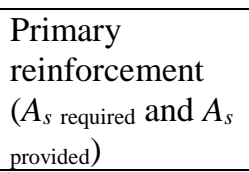 & Difference & $\begin{array}{l}\text { Shear } \\
\text { reinforcement } \\
\left(A_{h \text { required }} \text { and }\right. \\
\left.A_{h \text { provided }}\right) \\
\end{array}$ & Difference \\
\hline \multirow[t]{2}{*}{$\begin{array}{l}\text { Conventio } \\
\text { nal Method }\end{array}$} & 2 & $300 \times 400$ & $200 \times 400$ & $\begin{array}{l}405.167 \mathrm{~mm}^{2} \\
422.544 \mathrm{~mm}^{2} \\
(2 \mathrm{D} 13+2 \mathrm{D} 10)\end{array}$ & $\begin{array}{l}17.377 \mathrm{~mm}^{2} \\
(4.289 \%)\end{array}$ & $\begin{array}{l}142.664 \mathrm{~mm}^{2} \\
169.646 \mathrm{~mm}^{2}\end{array}$ & $\begin{array}{l}26.982 \mathrm{~mm}^{2} \\
(18.913 \%)\end{array}$ \\
\hline & 2 & $300 \times 400$ & $200 \times 400$ & $\begin{array}{l}474.438 \mathrm{~mm}^{2} \\
480.664 \mathrm{~mm}^{2} \\
\text { (2D16+1D10) }\end{array}$ & $\begin{array}{l}6.226 \mathrm{~mm}^{2} \\
(1.312 \%)\end{array}$ & $\begin{array}{l}119.838 \mathrm{~mm}^{2} \\
120.763 \mathrm{~mm}^{2}\end{array}$ & $\begin{array}{l}0.925 \mathrm{~mm}^{2} \\
(0.772 \%)\end{array}$ \\
\hline
\end{tabular}

Table 2. The differences between $A_{s}$ provided and $A_{h}$ provided both methods

\begin{tabular}{|c|c|c|c|c|}
\hline Method & $A_{s \text { provided }}$ & Difference & $A_{h \text { provided }}\left(\mathrm{mm}^{2}\right)$ & Difference \\
\hline Conventional Method & $422.544 \mathrm{~mm}^{2}$ & $\begin{array}{c}58.120 \mathrm{~mm}^{2} \\
(13.755 \%)\end{array}$ & 169.646 & $\begin{array}{c}48.883 \mathrm{~mm}^{2} \\
(28.815 \%)\end{array}$ \\
\hline STM & $480.66 \mathrm{~mm}^{2}$ & & 120.763 & \\
\hline
\end{tabular}

\subsection{Material properties}

The compressive strength of concrete was $30.998 \mathrm{MPa}$. The types and mechanical properties of used steel bars are given in Table 3.

Table 3. Mechanical properties of used steel bars

\begin{tabular}{llll}
\hline $\begin{array}{l}\text { Diameter } \\
(\mathrm{mm})\end{array}$ & $\begin{array}{l}f_{y} \\
(\mathrm{MPa})\end{array}$ & $\begin{array}{l}f_{u} \\
(\mathrm{MPa})\end{array}$ & $\varepsilon_{u}$ \\
\hline 6 & 379.907 & 523.307 & 0.2697 \\
10 & 492.757 & 710.787 & 0.2353 \\
13 & 457.400 & 659.557 & 0.2730 \\
16 & 448.573 & 635.250 & 0.2640 \\
\hline
\end{tabular}

\subsection{Testing setup}

The axial column was tested under $50 \mathrm{kN}$ fixed loads and the corbel was tested under monotonic loads at the specific point. The loads were gradually increased up to failure. The loading scheme of specimens is shown in Figure 8 and the test setup for specimens is shown in Figure 9. Equipment used for testing were as follows: supporting blocks, hydraulic jack, hydraulic pump, load cell, LVDT, data logger, strain gauges, etc. The deflection, strain of reinforcement, and crack pattern were closely observed.

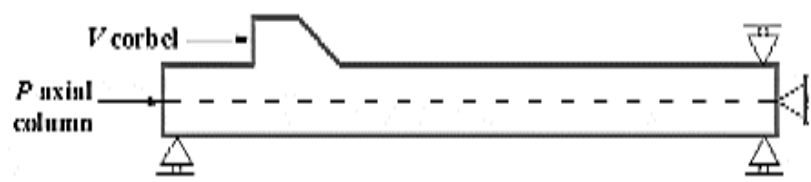

Figure 8. The loading scheme of specimen (top view)

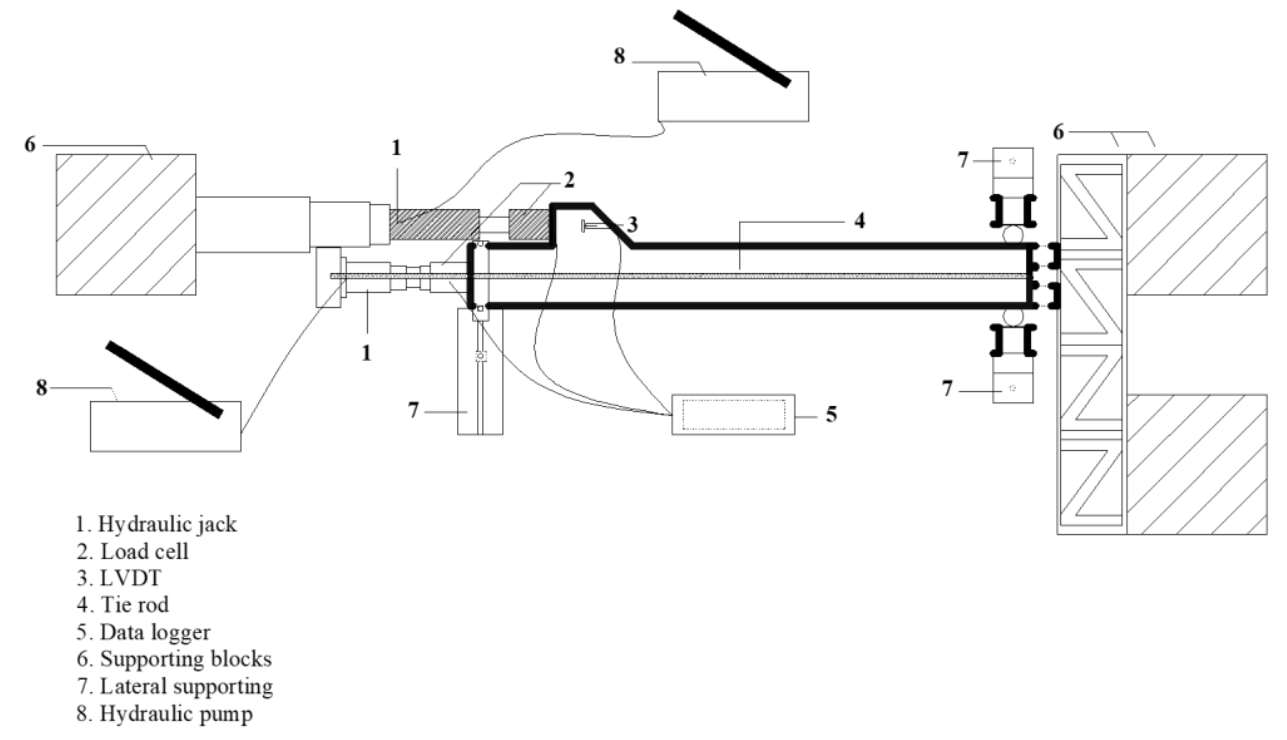

Figure 9. Test setup for specimens (top view). 


\section{RESULTS AND DISCUSSION}

\subsection{Cracking process}

The cracks of corbel are usually mostly vertical or steeply inclined pure shear cracks. The extended of cracks as the load increased is not always a propagation from the previous crack. Even, the increase of load can cause other new cracks at another surface, or the cracks become widen and extend the previous crack

Generally, all the corbel specimens showed the same response up to failure. The crack started from the point of application of the concentrated load and propagate diagonally towards the connection of corbel and column. On further loading, these cracks propagated downwards towards the column and the crack surface became widened. The recapitulation of the load at the first crack is shown in Table 4 and the crack patterns for four specimens at ultimate load are shown in Figure 10 to Figure 15. It can be seen that the propagation of crack patterns and the failure of specimens designed using both methods was a shear failure and more brittle.

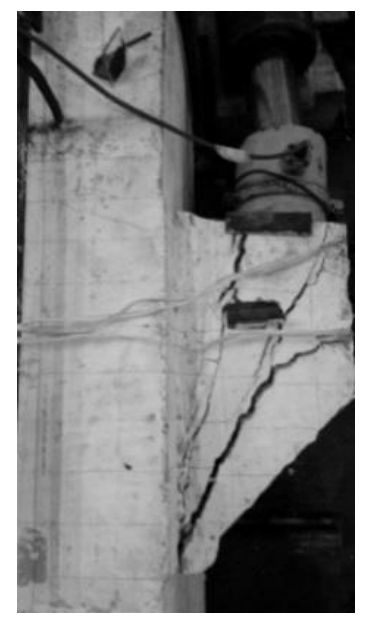

(a) side view

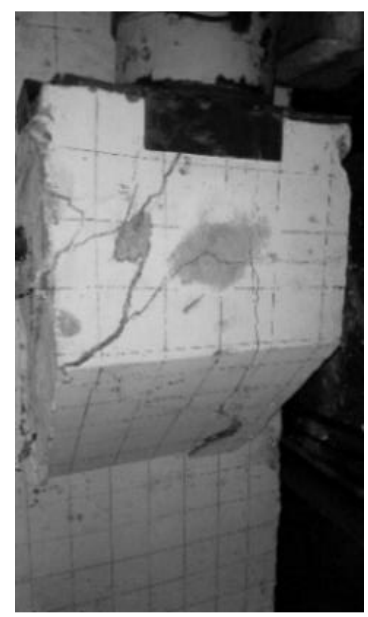

(b) front view
Figure 10. The crack pattern of specimen KpSNI-01 at ultimate load.

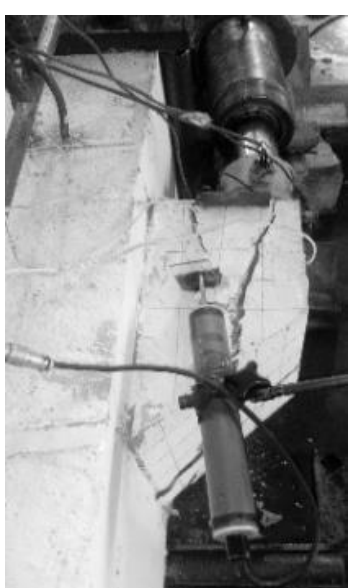

(a) side view

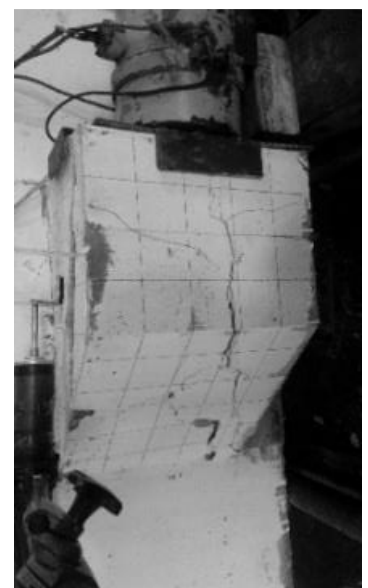

(b) front view
Figure 11. The crack pattern of specimen KpSNI-02 at ultimate load

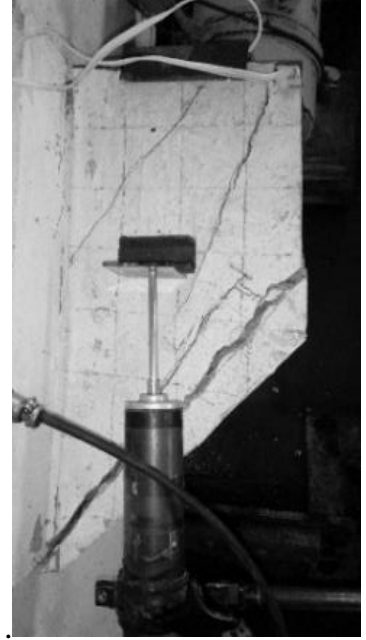

(a) side view

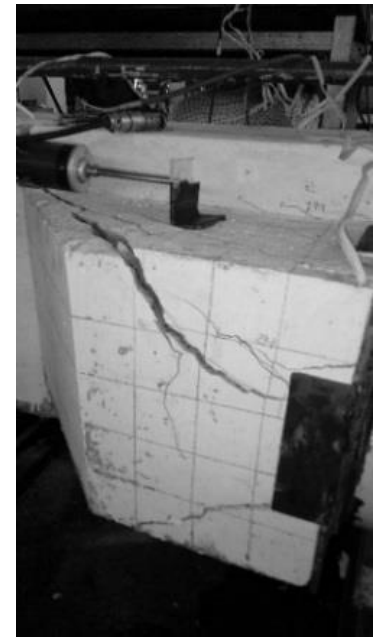

(b) front view
Figure 12. The crack pattern of specimen KpSTM-01 at ultimate load.

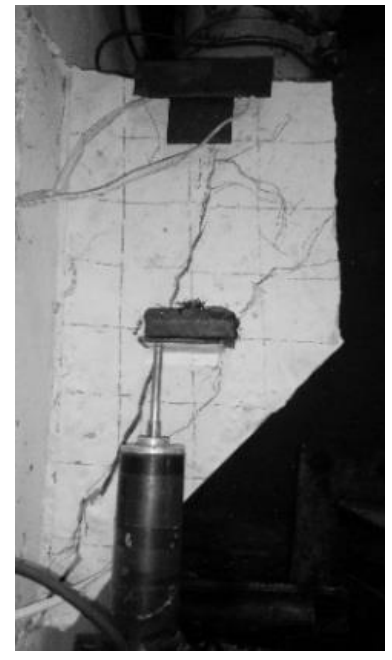

(a) side view

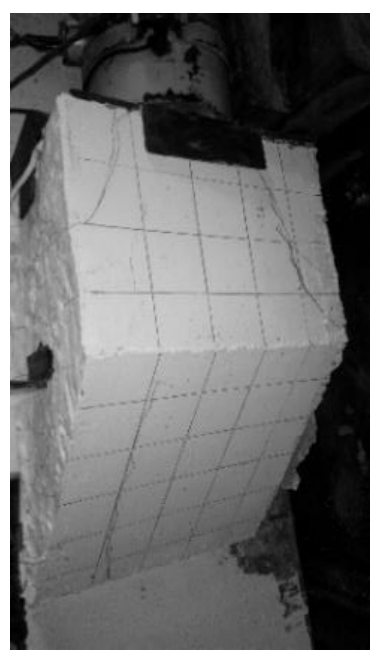

(b) front view
Figure 13. The crack pattern for specimen KpSTM-02 at ultimate load.

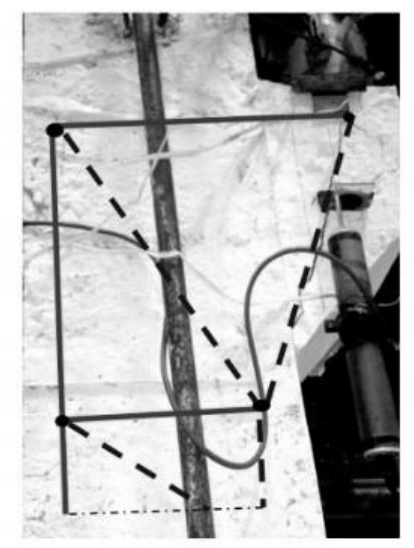

(a) KpSTM-01

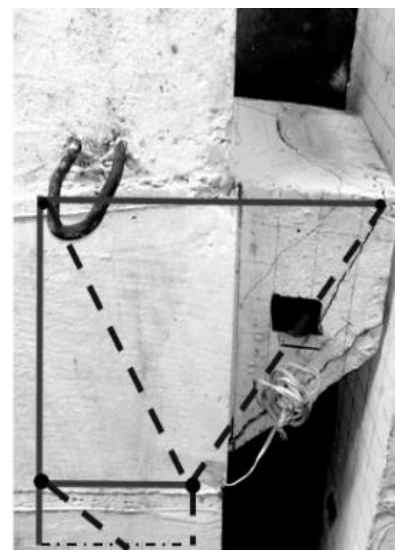

(b) KpSTM-02
Figure 14. The crack pattern and STM model of (a) specimen KpSTM-01, and (b) KpSTM-02. 
Table 4. Load at the first crack

\begin{tabular}{ll}
\hline Specimens & $P_{c r}(\mathrm{kN})$ \\
\hline KpSNI-01 & 225.6 \\
KpSNI-02 & 243.4 \\
KpSTM-01 & 273.1 \\
KpSTM-02 & 266.7 \\
\hline
\end{tabular}

\subsection{Load-deflection curves}

The load-deflection curves for corbels designed using conventional and STM method given in Figure 16 and Figure 17 while the combined of both curves shown in Figure 18. The deflection measured was not a pure deflection of corbel but rather the deflection of a structural system consisted of the deflection due to axial loading at the column and due to loading on the corbel itself, while the recapitulation of load and deflection at the first crack and ultimate load are given in Table 5. All specimens designed using both methods presented a nearly linear behavior up to failure. Applied load decreased suddenly once attained the peak point.

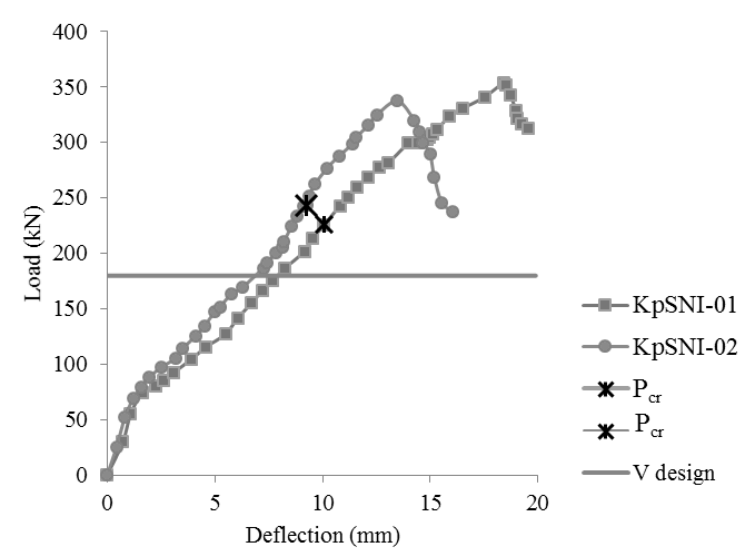

Figure 15. Load-deflection curves designed using conventional method.

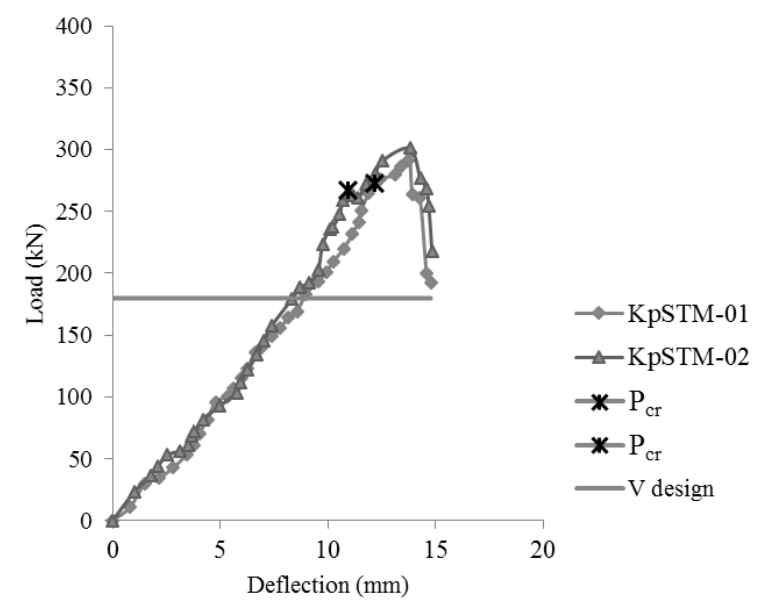

Figure 16. Load-deflection curves designed using STM method.

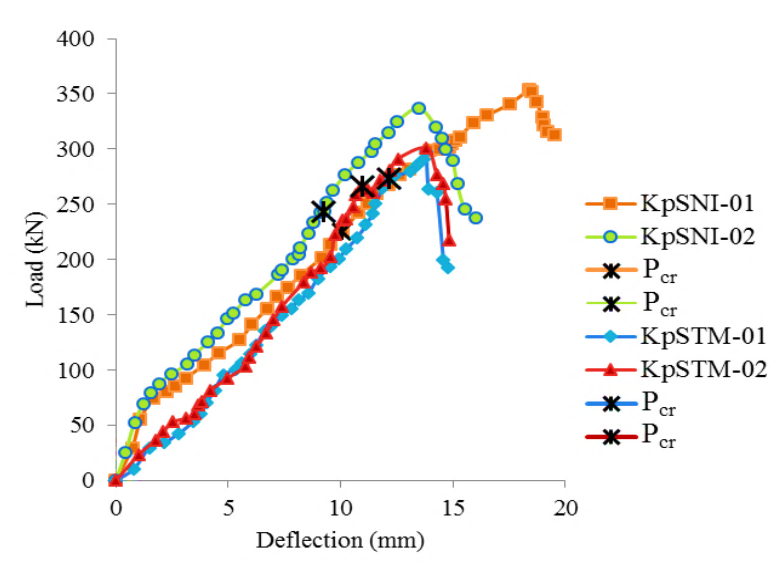

Figure 17. Load-deflection curves designed using both methods.

Table 5. The recapitulation of load and deflection at the first crack and ultimate load

\begin{tabular}{lllll}
\hline \multirow{2}{*}{ Specimens } & \multicolumn{2}{l}{ Load $(\mathrm{kN})$} & \multicolumn{2}{l}{ Deflection $(\mathrm{mm})$} \\
\cline { 2 - 5 } & $\begin{array}{l}\text { First } \\
\text { crack }\end{array}$ & Ultimate & $\begin{array}{l}\text { First } \\
\text { crack }\end{array}$ & Ultimate \\
\hline KpSNI-01 & 225.6 & 354.1 & 10.07 & 18.41 \\
KpSNI-02 & 243.4 & 337.3 & 9.25 & 13.47 \\
KpSTM-01 & 273.1 & 297.7 & 12.18 & 13.80 \\
KpSTM-02 & 266.7 & 301.0 & 10.95 & 13.81 \\
\hline
\end{tabular}

It can be seen from the experimental results that the ultimate load of specimens designed using conventional method was greater than the specimens designed using Strut and Tie Model. This difference was due to different area and arrangement reinforcement steel between the two methods. The details of arrangement reinforcement steel as shown in Figure 6 and Figure 7.

The specimens designed using conventional method have a shear reinforcement $\left(A_{h}\right)$ distributed uniformly within $2 / 3 d$ adjacent and parallel to primary tension reinforcement $\left(A_{s}\right)$, while the shear reinforcement of specimens designed using STM was placed on the tension area according to the truss model consisted of struts and ties. Table 1 shows that conventional method's specimens have a larger area of shear reinforcement than STM's specimens.

\subsection{Strain Gauge Analysis}

Strain gauges were placed along the steel bars of corbel to record the strain of the steel. For conventional method's specimens, the strain gauges were placed at main reinforcement 13D, 10D, and stirrup reinforcement $6 \mathrm{P}$, while for STM's specimens the strain gauges were placed at main reinforcement $16 \mathrm{D}$, $10 \mathrm{D}$, and stirrup reinforcement 6P. Load and strain curves are shown in Figure 19 to Figure 22. 


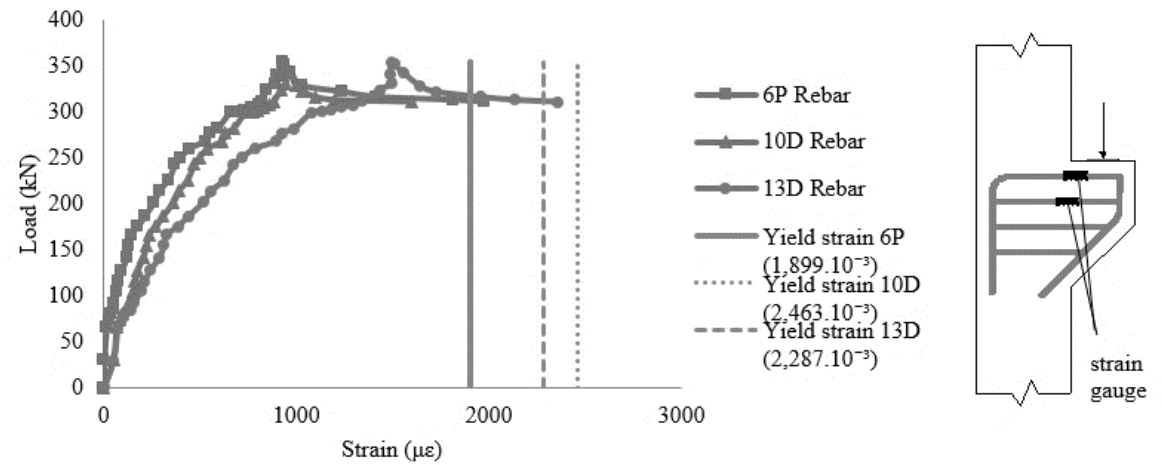

Figure 18. Load and strain curves of KpSNI-01 specimen.

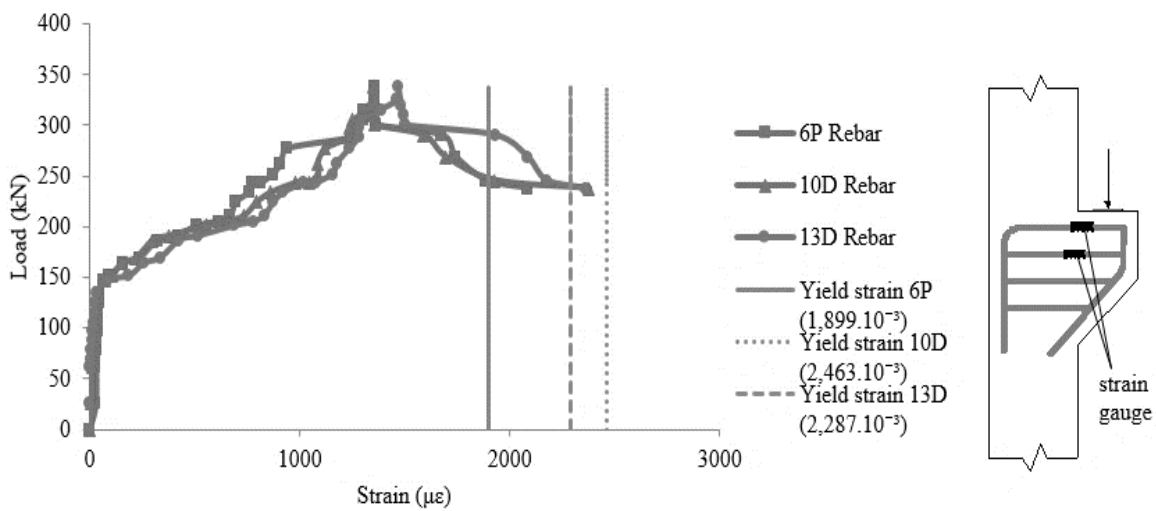

Figure 19. Load and strain curves of KpSNI-02 specimen.

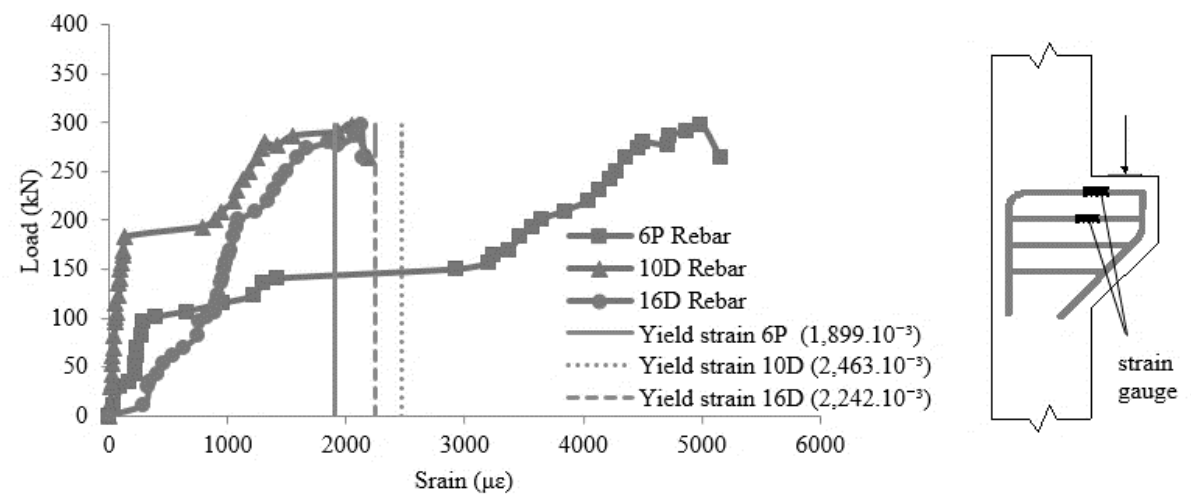

Figure 20. Load and strain curves of KpSTM-01 specimen.
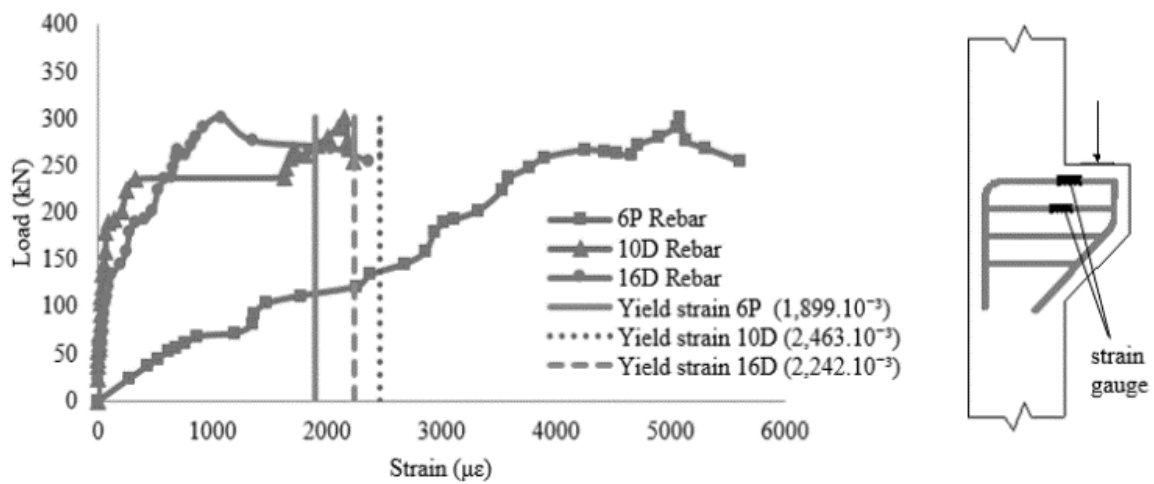

Figure 21. Load and strain curves of KpSTM-02 specimen. 
Generally, for both methods, the stirrup reinforcement has been reached the yield strain while none of the main reinforcement has reached the yield strain.

It can be concluded that for both methods, the failure has been caused by the compression of the struts and none of the main longitudinal steel bars has been observed as yielded at the failure of corbels.

4.4 Comparison between Design Load Capacity, Analytical Load Capacity and Experimental Results Load Capacity based on Conventional Method and STM

All specimens of both methods were designed using same design load and obtained a different area and arrangement of reinforcement steel, which then tested experimentally. Ultimate load capacities from the test results for each design method are shown in Table 5.

In the following Table 6 are shown the difference between design load capacity $\left(V_{\text {design }}\right)$, analytical load capacity $\left(V_{\text {analysis }}\right)$ and experimental load capacity ( $\left.V_{\text {experimental }}\right)$. It can be seen that there is a considerable difference between $V_{\text {design }}$ with $V_{\text {analysis }}$ and $V_{\text {experimental }}$. This is due to differences in parameters used when designing with the actual parameters in the laboratory such as the compressive strength of concrete and tensile strength of steel.

Table 6. Comparison of $V_{\text {design }}, V_{\text {experimental }}$ and $V_{\text {analysis }}$

\begin{tabular}{llll}
\hline Specimens & $\begin{array}{l}V_{\text {design }} \\
(\mathrm{kN})\end{array}$ & $\begin{array}{l}V_{\text {exp }} \\
(\mathrm{kN})\end{array}$ & $\begin{array}{l}V_{\text {analysis }} \\
(\mathrm{kN})\end{array}$ \\
\hline KpSNI-01 & 179.757 & 354.1 & 363.164 \\
KpSNI-02 & 179.757 & 337.3 & \\
KpSTM-01 & 179.757 & 297.7 & 306.953 \\
KpSTM-02 & 179.757 & 301.0 & \\
\hline
\end{tabular}

\subsection{Comparison between Analytical and Experimental Result}

Based on the compressive strength and the actual tensile strength of steel from laboratory test, the load capacity (shear capacity) has been calculated by analysis and compared to the experimental load capacity.

\subsubsection{Comparison between Analytical Shear Capacity using conventional method with Experimental Result.}

According to SNI 2847:2013 the shear strength provided by concrete is:

$V_{c}=0,17 \cdot \lambda \cdot \sqrt{f^{\prime}{ }_{c}} b_{w} d$
Where $V_{c}$ is shear strength provide by concrete, $\lambda$ is modification factor reflecting the reduced mechanical properties of lightweight concrete ( for normal weight concrete $\lambda=1), f_{c}^{\prime}$ is the compressive strength of concrete, $b_{w}$ is the width of the member, and $d$ is the effective depth of the member.

Shear strength provided by shear reinforcement:

$V_{s}=\frac{A_{v} f_{y} d}{s}$

Where $V_{s}$ is shear strength provided by shear reinforcement, $A_{v}$ is the area of shear reinforcement, $f_{y}$ is yield strength of reinforcement, $d$ is the effective depth of the member, and $s$ is the spacing of shear reinforcement.

So that, the nominal shear strength of corbel is:

$V_{n}=V_{c}+V_{s}$

The calculation of shear capacity of corbel using the conventional method and the comparison with the experimental result is given in Table 7 and Table 8 .

Table 7. The calculation of shear capacity using conventional method

\begin{tabular}{cccc}
\hline Specimens & $\begin{array}{c}V_{c} \\
(\mathrm{kN})\end{array}$ & $\begin{array}{c}V_{s} \\
(\mathrm{kN})\end{array}$ & $\begin{array}{c}V_{n}=V_{c}+V_{s} \\
(\mathrm{kN})\end{array}$ \\
\hline KpSNI-01 & 81.196 & 281.967 & 363.164 \\
KpSNI-02 & 81.196 & 281.967 & 363.164 \\
\hline
\end{tabular}

Table 8 . Comparison between shear capacity $V_{\text {analysis }}$ and $V_{\text {experimental }}$

\begin{tabular}{|c|c|c|c|c|}
\hline Specimens & $\begin{array}{c}V_{\text {analysis }} \\
(\mathrm{kN})\end{array}$ & $\begin{array}{l}V_{\text {exp }} \\
(\mathrm{kN})\end{array}$ & $\begin{array}{c}V_{\text {exp }} / \\
V_{\text {analysis }}\end{array}$ & $\begin{array}{c}\text { Difference } \\
\quad(\%)\end{array}$ \\
\hline KpSNI-01 & 363.164 & 354.1 & 0.975 & 2.559 \\
\hline KpSNI-02 & 363.164 & 337.3 & 0.928 & 7.667 \\
\hline & Mean & 345.7 & 0.952 & 5.113 \\
\hline
\end{tabular}

It can be concluded that the difference between analytical shear capacity and experimental shear capacity is $5.113 \%$.

\subsubsection{Comparison between Analytical Shear Capacity using SNI method with Experimental Result.}

Based on truss analogy model proposed by Franz and Niedenhoff (1963), Hagberg (1983) described a mathematical model to determine the capacity, that may be applied to all types of reinforcement (main and 
secondary), covering the practical range of $\left(a_{1} / d\right)$ ratio from 0.15 to 1.5 and for any combination of horizontal and vertical loads. Figure 22 shows geometry, forces, and equilibrium conditions of the corbel.

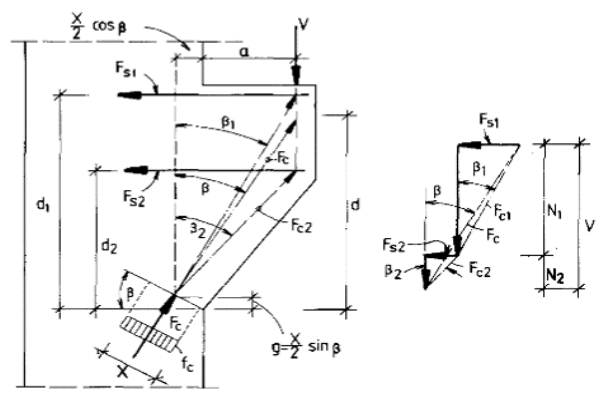

Figure 22. Geometry, forces, and equilibrium conditions of corbel.

Hagberg (1983) proposed the following formulas:

$\left(1-\frac{2 \cdot f^{\prime}{ }_{c} \cdot b \cdot d}{F_{s}}\right) \cdot \tan ^{2} \beta+\left(\frac{2 \cdot f^{\prime}{ }_{c} \cdot b \cdot a}{F_{s}}\right) \cdot \tan \beta+1=0$

where $f^{\prime}{ }_{c}$ is the compressive strength of concrete, $b$ is the width of the member, $d$ is the effective depth of the member, $F_{s}$ is total force of main reinforcement and secondary (shear) reinforcement, $\beta$ is inclination compression strut with the vertical, and $a$ is the shear span.

$d=\frac{d_{1} \cdot F_{s 1}+d_{2} \cdot F_{s 2}}{F_{s}}$

Where $d_{1}$ and $d_{2}$ are the distance of main reinforcement and the center of gravity of the secondary reinforcement respectively, and $F_{\mathrm{s} 1}$ and $F_{\mathrm{s} 2}$ are the force of main reinforcement and secondary reinforcement. Based on Figure 22 the following equations can be obtained:

a) Equilibrium conditions

$$
\begin{aligned}
& F_{c}=V / \cos \beta \\
& F_{s}=V \cdot \tan \beta \\
& F_{s}=F_{s 1}+F_{s 2}
\end{aligned}
$$

$$
V=N_{1}+N_{2}=\frac{F_{s 1}}{\tan \beta_{1}}+\frac{F_{s 2}}{\tan \beta_{2}}
$$

b) Geometry

$$
\begin{array}{r}
\tan \beta_{1}=\frac{a+\frac{x}{2} \cos \beta}{d_{1}-\frac{x}{2} \sin \beta} \\
\tan \beta_{2}=\frac{a+\frac{x}{2} \cos \beta}{d_{2}-\frac{x}{2} \sin \beta}
\end{array}
$$

c) Strength of materials

$$
\begin{aligned}
& F_{c}=f_{c} \cdot b \cdot x \\
& F_{s 1}=A_{s 1} \cdot f_{s 1} \\
& F_{s 2}=A_{s 2} \cdot f_{s 2}
\end{aligned}
$$

If Equation (20) and Equation (21) combined with Equation 26 will be obtained:

$$
x=\frac{F_{s}}{f_{c} b \cdot \sin \beta}
$$

Based on the equations above, the shear capacity of corbels using STM method can be calculated. The calculations of shear capacity are given in Table 9 to Table 13.

Previously, it was known the failure of specimens has been caused by the compression of the struts. Based on Equation (20), the shear capacity ( $V$ ) of corbels can be calculated with the equation as follow:

$V=F_{c} \cdot \cos \beta$

$F_{\mathrm{c}}$ is the strength of strut and calculated with Equation (26) $\left(F_{c}=f_{c} \cdot b \cdot x\right)$, where $f^{\prime}{ }_{c}$ is the compressive strength of concrete, $b$ is the width of the member, and $x$ is the width of the strut.

Table 9. The calculation of $F_{\mathrm{s} 1}$ and $F_{\mathrm{s} 2}$

\begin{tabular}{llllllll}
\hline$A_{s l}\left(\mathrm{~mm}^{2}\right)$ & & $f_{y l}(\mathrm{MPa})$ & & $A_{s 2}\left(\mathrm{~mm}_{2}\right)$ & $f_{\mathrm{y} 2}(\mathrm{MPa})$ & \multirow{2}{*}{$F_{s l}(\mathrm{kN})$} & \multirow{2}{*}{$F_{s 2}(\mathrm{kN})$} \\
\hline $\mathrm{D} 16$ & $\mathrm{D} 10$ & $\mathrm{D} 16$ & $\mathrm{D} 10$ & $2 \mathrm{P} 6$ & $\mathrm{P} 6$ & 219.084 & 42.966 \\
\hline 402.124 & 78.539 & 448.573 & 492.757 & 113.097 & 379.907 & 219 \\
\hline
\end{tabular}

Table 10. The calculation of $d$

\begin{tabular}{cccccc}
\hline$d_{1}(\mathrm{~mm})$ & $d_{2}(\mathrm{~mm})$ & $F_{s l}(\mathrm{kN})$ & $F_{s l}(\mathrm{kN})$ & $F_{s}(\mathrm{kN})$ & $d(\mathrm{~mm})$ \\
\hline 350 & 50 & 219.084 & 42.966 & 262.049 & 300.811 \\
\hline
\end{tabular}


Table 11. The calculation of $\beta$

\begin{tabular}{cccccc}
\hline$a(\mathrm{~mm})$ & $b(\mathrm{~mm})$ & $d(\mathrm{~mm})$ & $f^{\prime} \mathrm{c}(\mathrm{MPa})$ & $F_{\mathrm{s}}(\mathrm{kN})$ & $\beta$ \\
\hline 100 & 250 & 300.811 & 30.998 & 262.049 & 28.555 \\
\hline
\end{tabular}

According to SNI 2847:2013 Appendix A mentioned in Equation (11) in the previous chapter, the effective compressive strength of the concrete $f_{c e}$ in a strut shall be taken as $f_{c e}=0,85 \beta_{s} . f^{\prime}{ }_{c}$. So that, the strength of compression of the struts in Equation (26) can be calculated as:

$$
F_{c}=f_{c e} \cdot b \cdot x=0,85 \beta_{s} f^{\prime}{ }_{c} b \cdot x
$$

Table 12. The calculation of shear capacity using STM method

\begin{tabular}{cccccc}
\hline $\begin{array}{c}f^{\prime} \mathrm{c} \\
(\mathrm{MPa})\end{array}$ & $\begin{array}{c}b \\
(\mathrm{~mm})\end{array}$ & $\begin{array}{c}x \\
(\mathrm{~mm})\end{array}$ & $F_{\mathrm{c}}$ & $\cos \beta$ & $\begin{array}{c}V \\
(\mathrm{kN})\end{array}$ \\
\hline 30.998 & 250 & 70.737 & 349.462 & 0.878 & 306.953 \\
\hline
\end{tabular}

Table 13. Comparison between shear capacity $V_{\text {analysis }}$ and

$V_{\text {experimental }}$

\begin{tabular}{lllll}
\hline Specimens & $\begin{array}{l}V_{\text {analysis }} \\
(\mathrm{kN})\end{array}$ & $\begin{array}{l}V_{\text {exp }} \\
(\mathrm{kN})\end{array}$ & $\begin{array}{l}V_{\text {exp }} / \\
V_{\text {analysis }}\end{array}$ & $\begin{array}{l}\text { The } \\
\text { difference } \\
(\%)\end{array}$ \\
\hline KpSTM-01 & 306.953 & 297.7 & 0.969 & 3.108 \\
KpSTM-02 & 306.953 & 301 & 0.981 & 1.978 \\
\hline & Mean & 299.35 & 0.975 & 2.543 \\
\hline
\end{tabular}

It can be concluded that the difference between analytical shear capacity and experimental shear capacity is $2.543 \%$.

\section{CONCLUSIONS}

Some conclusions that can be drawn from the results are as follows:

a) The design with the conventional method (SNI 2847:2013 Chapter 11.8) and STM method (SNI 2847:2013 Appendix A) with same design load obtained a different area and arrangement of reinforcement steel. Conventional method obtained 2D13+2D10 $\left(A_{s}=422.544 \mathrm{~mm}^{2}\right)$ for primary reinforcement and 3P6-80 $\left(A_{h}=169.646\right.$ $\mathrm{mm}^{2}$ ) for shear reinforcement, while STM method obtained 2D16+1D10 $\left(A_{s}=480.664 \mathrm{~mm}^{2}\right)$ for primary reinforcement and 2P6-50 $\left(A_{h}=120.763\right.$ $\mathrm{mm}^{2}$ ) for reinforcement at tension area.

b) The results showed that with the provided steel and the compressive strength of concrete, the shear capacity using the conventional method by analysis and experimental respectively were $363.164 \mathrm{kN}$ and $345.7 \mathrm{kN}$. The difference between analytical and experimental shear capacity using conventional method was $5.113 \%$. While the shear capacity using STM method by analysis and experimental respectively were $306.953 \mathrm{kN}$ and $299.35 \mathrm{kN}$. The difference between analytical and experimental shear capacity using STM method was $2.543 \%$.

c) The ultimate load (Shear Capacity) of specimens with conventional method was $46.35 \mathrm{kN}$ or 13.40 $\%$ greater than STM method's. This difference was due to different area and arrangement reinforcement steel between the two methods.

d) The crack and failure patterns of corbels that designed with the conventional method and Strut and Tie Method both generally were shear failures and brittle. The failure of specimens has been caused by the compression of the struts

\section{REFERENCES}

ACI Committee, 2002. Building code requirements for structural concrete : (ACI 318-02) and commentary (ACI 318R-02), Farmington Hills: American Concrete Institute.

ACI Committee, 2005. Building Code Requirements for Structural Concrete and Commentary \& PCA Notes on 318-05, Farmington Hills: American Concrete Institute.

ACI Committee, 2011. Building Code Requirements for Structural Concrete (ACI 318M-11), Farmington Hills: American Concrete Institute.

ACI Committee, 2014. Building Code Requirements for Structural Concrete and Commentary ACI 318-14, Farmington Hills: American Concrete Institute.

Attaullah, S., Ehsanul, H. \& Salimullah, K., 2011. Analysis and Design of Disturbed Regions in Concrete Structures. Procedia Engineering, pp. 3317-3324.

Fu, C. C., Sircar, M. \& Robert, J., 2011. Maryland Experience in Using Strut-and-Tie Model in Infrastructures.

Ministry of Public Works, 2013. SNI 2847:2013 Persyaratan Beton Struktural untuk Bangunan Gedung, Jakarta: Ministry of Public Works. 
[this page is intentionally left blank] 